\title{
Can Backward-looking and Forward-looking Information Debias the Prospect Effect in Earnings Announcements?
}

\author{
Jogiyanto Hartono, ${ }^{*}$ and Sri Wahyun ${ }^{2}$ \\ ${ }^{1}$ Faculty of Economics and Business, Universitas Gadjah Mada, Indonesia \\ ${ }^{2}$ Institute of Economic Science (STIE) Mahardhika Surabaya, Indonesia
}

\begin{abstract}
This study examines the important issue of whether additional pieces of information about the earnings' characteristics (their quantitative description and predicted earnings) can debias the prospect effect of the earnings' announcement. The prospect effect bias can be mitigated by the availability of clear information and an integrated disclosure. Additional information that is included with the previous information will make the investors' beliefs stronger and it will debias any psychological effects. This research confirms the prospect effect's bias that investors react more negatively when evaluating a company's performance after a negative earnings information disclosure rather than react positively in evaluating the performance for a positive earnings information disclosure. The results also show that when additional pieces of information, such as a quantitative description and predicted earnings are added, they can mitigate the prospect effect's bias. Additional information of predicted earnings as forward-looking oriented information has a stronger debiasing effect than that of additional information of a quantitative description as backward-looking oriented information.
\end{abstract}

Keywords: backward-looking oriented information; debias; forward-looking oriented information; mitigating bias; predicted earnings; prospect theory; quantitative description

JEL classification: D81

* Corresponding author's e-mail: jogiyantohm@gmail.com 


\section{Introduction}

The prospect effect is confirmed when investors react more negatively in evaluating a company's performance after its negative earnings information disclosure rather than when they react positively to evaluate the same company's performance for its positive earnings information disclosure (Schrand and Walther 2000; Krische 2005). Previous research already showed that a single accounting information disclosure can cause the prospect effect's bias when used by investors to make their investment decisions. Examples are studies by Ferris et al. (1988), Lakonishok and Seymour (1989) and Odean (1998).

Since the prospect effect's bias reflects irrational investors' inaccurate decision making, it is important to conduct research to mitigate this bias. Schrand and Walther (2000) and Krische (2005) indicated that investors adjust for the prior-period event when an additional clear quantitative description is presented in the current-period announcement. Using this idea, this study attempts to use additional pieces of information that are believed to revise investors prior beliefs, to reduce the decision-making bias.

This research tries to test single and multiple pieces of information in earnings announcements, based on the prospect theory (Kahneman and Tversky 1979). The single earnings information announcement is used to test the prospect effect's bias. While the multiple pieces of information in earnings announcements are used to test the debiasing effect of the prospect effect's bias.

The underlying assumption is the presence of bounded rationality (Bazerman 1994), which is the condition of an individual who has limitations on the information, memory, capacity, time, and other things available to him/her, so the individual does not have backward- and forward-looking oriented prospectus information, unless the information is expressed in any current announcements (Wahyuni and Hartono 2010). The involvement of the psychological aspect in this study is in line with Bernard (1989) and Hartono (2004) who suggested that the research should adopt a new way to think about the market by considering the cognitive-psychological aspect.

In contrast to previous empirical research, this study uses the prospect theory to explain characteristics of the earnings' information disclosures in a company's performance evaluation setting. Studies into the characteristics of earnings information disclosures are not frequently carried out, but there have been studies by Schrand and Walther (2000) and Krische (2005). They are pioneers in studying the characteristics of the earnings' information disclosure. The characteristic of the earnings' information disclosures they used is the transitory gain or loss on the disposal of Property, Plant and Equipment (PPE) in the current period's announcement of the earnings. They show that every item that is disclosed in the earnings' announcements is expected to affect the perception of potential investors.

Two characteristics of an earning's information disclosure, as additional pieces of information used in this study, are qualitative description information as a proxy of backward-looking oriented information, and predictive earnings information as a proxy of forward-looking oriented information. The quantitative description information in this study is the management's explanation regarding the increase or decrease in sales stated in the earning's announcement. The quantitative description's disclosure in an earning's 
announcement can clarify any previous quantitative information, thus reducing the occurrence of the perception bias (Schrand and Walther 2000; Krische 2005, Wahyuni and Hartono 2012).

Predicted earnings information is the management's guidance about future information. King et al. (1990) used management earnings forecasts as an earnings' prediction. Widely, Baginski et al. (2004) stated that management often explains its earnings' prediction through an attribution related to estimated performance. Such an attribution can be about the company's internal activities (e.g. products and services, and organizational issues) or the company's external activities (e.g. economic conditions, or government regulations). The attribution potentially helps investors to interpret the management's forecast, even more so in the event of a possible negative forecast (bad news forecast). Not only does the management's guidance contains information (Patell 1976; Penman 1980; Waymire 1984), but it is also seen to have better quality information about the foreseeable future than that contained in many analysts' forecasts (Ajinkya and Gift 1984; Patell 1976; Baginski et al. 2004). Therefore, this study uses predicted earnings as management guidance information to proxy the forward-looking information (Hartono and Wahyuni 2014).

There are some matters that motivate this research as follows: first, this study not only uses single information but also uses multiple pieces of information to test the prospect effect. Second, this study is one of the few studies that use additional pieces of information, in terms of a quantitative description as backward-looking information, and an earnings' prediction as forward-looking oriented piece of information. Third, this study uses an experimental research design with real investors as the exeriment's subjects, which is rare in market based accounting research and is expected to inspire the development of experimental research in this field.

The contributions of this research include theoretical, methodological, practical, and policy contributions. The theoretical contribution is given by providing evidence on the debiasing prospect effect in an accounting environment. This research supports the prospect effect and how to debias the effect. The results of this research are expected to trigger further research into the behavioral aspects of accounting.

The methodological contribution in this research relates to the use of the experimental design. Experimental research itself into the behavioral aspects of accounting research is not a new thing, but it is rare in accounting capital market research. Experimental material, with the setting of investors' behavior about performance evaluations, will further inspire the development of experiment material in the field of capital market research.

This study is expected to contribute to how firms determine their announcement strategies to avoid any decision-making bias in the reactions of their investors. Firms can use additional pieces of information to mitigate the investors' bias when they disclose a negative earning's announcement.

The last is for the contribution to policy making. For the regulator, as the accounting standard's setter, the results of this research can be an important input, to be used as a consideration when making financial reporting disclosure standards. Since earnings announcements can create prospect bias, the regulator can force firms to disclose additional pieces of information, especially those of for- 
ward-looking oriented information, to reduce and even to mitigate the bias.

In the experiment, investors interpret a company's earnings announcement and forecast the next period's earnings. First, the investors receive the company's business description, manipulated between subjects to be either positive or negative information. This study further manipulates, within the subjects, whether the investors used the characteristics of the information as a basis for evaluating the company's performance (three types of cases) and determining the estimated earnings for the coming year. Then the subjects are given information of an increase or a decrease in the estimated earnings compared with the amount of current earnings. The subjects also answer questions about the manipulation check.

Consistent with Schrand and Walther (2000), Krische (2005) and Wahyuni and Hartono (2010, 2012), this result indicates that additional information, which is integrated with previous information, will make investors' beliefs stronger, and it will debias the psychological effects, which in turn helps investors to evaluate the company's performance. This study provides evidence that single information in an earning's announcement produces a bias of the prospect effect, and any additional characteristics' disclosure of earnings information of a quantitative description as backward-looking information, and predicted earnings as forward-looking information can mitigate the prospect effect's bias. This study also finds that forward-looking oriented information is better at debiasing the prospect effect's bias than backwardlooking oriented information is.

\section{Theory and Hypotheses Development}

\section{Prospect Theory}

The prospect theory is one of the main pillars of the behavioral finance literature. This theory was introduced by Kahneman and Tversky (1979) as a decision-making theory in uncertain or risky conditions. The prospect theory explains how selections are framed and evaluated in the decision-making process.

The prospect theory states that individuals focus more on the prospect of gains and losses, not on total wealth. Their reference point is the status quo and assumes that everyone who uses it is familiar with it. The prospect theory predicts an individual would avoid risk (risk averse) when evaluating a choice above the reference point (gain domain) and tends to be risk seeking when evaluating choices under the reference point (loss domain). The prospect theory can explain the trade-off between two parameters when evaluating organizations, namely risk and return (Fiegenbaum and Thomas 1988; Fiegenbaum 1990; Jegers 1991; Sinha 1994). In particular, organizations below their target levels are found to be risk-takers, while organizations above their target levels are riskaverters. Kliger and Tsur (2011) explain the relationship between risk and return at the organization level; that firms with returns above their reference levels take less risks than do firms with returns below their reference levels.

The important element of the prospect theory is the reference dependence. The prospect theory's preference is not presented with 
a constant utility function, but it depends on the situation, and the expectations and norms of the individual, which develop from the basic psychology of human intuition. Stracca (2002) explains that the prospect theory is based on three assumptions as follows: first, organisms always adapt to their circumstances. Individuals determine that gain or loss is based on a reference point, not an absolute value. Investors' utility is assumed to be a function of the gains and losses relative to a benchmark, not a function of absolute wealth. Second, the marginal response is diminishing. The distance of the gains and losses from the reference point shows the decreasing sensitivity. Third, pain is more urgent than pleasure. Therefore, people are more sensitive to losses than gains, which means a reluctance to lose.

Most researchers who examined the riskreturn association under the prospect theory assumed a common reference point at the industry level, usually measured by the industry median or mean of returns. Fiegenbaum and Thomas (1988) and Fiegenbaum (1990) justified this selection. Lev (1969) and Frecka and Lee (1983) found that firms periodically adjust their performance and financial ratios to their industry means. Lehner (2000) found the validity of industry benchmarks to be reference level proxies.

\section{Quantitative Description and Predicted Earnings Information}

Quantitative description information is additional information, such as the manage- ment's explanation (management guidance) about events which have occured in one accounting period. The quantitative description information in this study is the management's explanation regarding an increase (decrease) in sales stated in a positive (negative) earnings' announcement. A quantitative description disclosure in the earnings' announcement can clarify the previous quantitative information, thus reducing the occurrence of the perception bias (Schrand and Walther 2000; Krische 2005, Wahyuni and Hartono 2012). A quantitative description is considered as backward-looking oriented information. It provides historical information to support the earnings' announcement information. ${ }^{1}$

Predicted earnings information is management's guidance about future information. ${ }^{2}$ Empirical studies about predicted earnings information have been conducted and obtained different results. A study by Han and Wild (1987) and Pownall and Waymire (1989) showed that earnings forecasts are assumed to be less credible than other sources of information, while other studies documented that earnings forecasts have an information content (Patell 1976; Penman 1980; Waymire 1984). The next development is related to the study of management guidance that is considered to have better quality future information than an analyst's forecast (Ajinkya and Gift 1984; Patell 1976; Baginski et al. 2004; Han and Tan 2007).

Baginski et al. (2004) explained an earning's forecast, as a type of prospectus information, related to the estimation of the

${ }^{1}$ Prior archival evidence (Schrand and Walther 2000) and an experimental setting (Krische 2005) provides evidence that investors evaluate a company more favorably when a clear, quantitative description of a prior-period gain is included in the current announcement and less favorably when a clear, quantitative description of a prior-period loss is included. Similarly, Wahyuni and Hartono's (2010,2012) experiment results suggest that a quantitative description of the priorperiod gain or loss influences the investors' judgments.

${ }^{2}$ For more information about management earnings forecasts see King et al. 1990. In this study, 'management guidance' is similar to management earnings forecast. 
performance of both a company's internal activities (e.g. product and service issues, organizational issues) and its external activities (e.g. economic conditions, or government regulations). Han and Tan (2007), by using an experiment, tested the disclosure of different forms of management guidance and indicated that investors tend to choose guidance in a range of forms, rather than in an absolute form. Both the study of earnings forecasts and the study of management guidance usually still focus on a single reference point.

\section{Hypotheses Development}

\section{Prospect Effect of Single Information Hypothesis}

According to Kahneman and Tversky (1979), the prospect theory predicts that an individual will avoid risks (risk averse) when evaluating choices above the reference point (gain domain) and tends to be risk seeking when evaluating choices below the reference point (loss domain). Schrand and Walther (2000), as well as Krische (2005) offer the support that investors often remember priorperiod gains more in a loss condition. This research result is strengthened by Wahyuni and Hartono (2012) who state that investors will process prior-period information, expressed in the current announcement, differently between information containing gain and loss transitories.

Boldt (2001) found that an individual behaves more/less favorably because of the fixation effect. Individuals would be fixated by historic earnings that contain loss/profit transitories when estimating future earnings. Similarly when it is related to the phenomenon of earnings characteristics' information disclosure, it is believed that positive earn- ings information disclosures will tend to make investors evaluate a company's performance higher, while negative earnings information will tend to cause investors to evaluate the company's performance lower, but the evaluation scale would be higher for negative earnings rather than positive earnings.

Kahneman and Tversky (1979) showed that psychologically people will react more to a loss situation than to a gain situation. Krische (2005) and Wahyuni and Hartono (2010) examined whether investors evaluate a company more favorably when information about a transitory prior-period gain, as positive information, is repeated in the currentperiod announcement and less favorably when information about a transitory prior-period loss, as negative information, is repeated. Those results suggest that the prospect effect's bias occurred, as the negative information caused a greater reaction than the positive information did.

Stracca (2002) explains that one of the three assumptions of the prospect theory is that pain is more urgent than pleasure, so people are more sensitive to losses than gains. Therefore, the prospect effect bias is hypothesized as follows.

$H_{i}$ : Investors will react more negatively in evaluating a company's performance based on a negative earning's information disclosure rather than react positively in evaluating the company's performance based on a positive earning's information disclosure.

\section{Debiasing Prospect Effect of Additional Multiple Pieces of Information Hypothesis}

Schrand and Walther (2000) examined the strategic prior-period benchmark disclosures in earnings announcements. They provided evidence that the managers' selective 
repetition of information about transitory prior-period events in the current earnings announcement affect investors' adjustments to the events, and their evaluations of earnings performance. Krische (2005) indicated that investors adjust for the prior-period event when a clear, quantitative description is presented in the current-period announcement, but not when the description is absent, even though investors had previously identified the event. The experiment's results by Wahyuni and Hartono (2012) suggested that the strategic disclosure of prior-period benchmarks influences the investors' judgments when evaluating performance.

Individuals tend to make their decisions based on the information which exists in their memories. The availability of information is deduced from a heuristic concept (Simon 1957; Kahneman and Tversky _1979). Based on this assumption, it can be explained that a quantitative description of prior-period gains or losses, and predicted earnings included in the current earnings announcement, will serve as clues and help investors to recall pieces of information already in their memories, which can be of great help to individuals in calculating the adjusted earnings (Krische 2005; Wahyuni and Hartono 2010, 2012).

A quantitative description information disclosure, as backward-oriented information, is management's explanation regarding the increase or decrease in sales provided in an earning's announcement. Additional quantitative description disclosures in earnings announcements can clarify the quantitative information, and thus can reduce the occurrence of perception bias (Schrand and Walther 2000; Krische 2005, Wahyuni and Hartono 2012). Similarly, recent research into comprehensive income disclosures (Maines and McDaniel 2000), and the accuracy of prior estimates (Hirst et al. 2003) has also documented that the presentation format used can affect analysts' and individual investors' evaluations of performance.

Predicted earnings information, as forward-oriented information, was examined by Baginski et al. (2004) and Han and Tan (2007). Baginski et al. (2004) stated that managers often explain their earnings forecasts through attributions related to their estimations of performance, both for the company's internal activities (e.g. product and service issues, organizational issues) and its external activities (e.g. economic conditions, or government regulations). The predicted earnings information in this study is defined as the earnings' forecast by the company's management, which is expressed as a percentage of the earnings, accompanied by a qualitative explanation of the concrete steps taken by the management to achieve their predicted earnings.

Additional quantitative descriptions and predicted earnings pieces of information that are disclosed in the earnings' announcements are expected to affect the perception of the investors, which would then be reflected in their behavior when they are making business decisions. The clear, quantitative description and predicted earnings information that are disclosed in the earnings' announcements would ensure that investors had sufficient information available for them to compute the adjusted earnings. Therefore, this study predicts that the additional quantitative description and predicted earnings information, when disclosed in the earnings' announcements, can mitigate the prospect effect's bias in estimating future earnings. It is hypothesized that additional pieces of information can debias the prospect effect's bias as $H_{2}$. 
$H_{2}$ : The additional pieces of information of the earnings' characteristics announcement (the quantitative description as backward-looking information and predicted earnings as forward-looking information) will debias the prospect effect of earnings announcement disclosure.

\section{Research Method}

\section{Experiment Design}

This research uses an experiment to test causality relations with some manipulated variables to answer the research problems. The experimental method is chosen for use in this study because it can control any tested and extraneous variables affecting the causality relations. The experiment in this study uses a combination of between-subjects and within-subjects designs, with a $2 \times 3$ mixed factorial design, as seen in Table 1 . The $2 \times 3$ experimental method in this research includes: (1) earnings information (two conditions: positive earnings and negative earnings); (2) earnings characteristic disclosure [three conditions: earnings information $(\mathrm{E})$, earnings information (E) plus quantitative description (QD), and earnings information
(E) plus quantitative description (QD) plus predicted parnings (PE)].

A between-subjects design compares earnings information between positive and negative earnings with subjects in different groups, to test the prospect effect's bias $\left(\mathrm{H}_{1}\right)$. The within-subjects design compares the effects of different treatments on the same subjects in a group. The different treatments are the information's content (earnings, earnings plus quantitative description and earnings plus quantitative description plus predicted earnings) which are used to test the debias prospect's effect $\left(\mathrm{H}_{2}\right)$.

In a between-subjects design, each subject gets a case description, while in the within-subjects design, each subject gets more than one case descriptions (Harsha and Knapp 1990). Moreover, it is explained that the use of the between-subjects experiment is based on the reason that the method is able to test the effect of any interaction from the independent variable toward the dependent variable, and to avoid the occurrence of the demand effect that occurs when the subjects know the direction, from the conditions given to them.

Table 1. Experiment Design 2 × 3

\begin{tabular}{llc}
\hline & \multicolumn{2}{c}{ Signs of Earnings Information } \\
\cline { 2 - 3 } Information Characteristics & Positive & Negative \\
\hline Earnings (E) & Cell 1a & Cell 2a \\
Earnings (E) + Quantitative Description (QD) & Cell 1b & Cell 2b \\
$\begin{array}{l}\text { Earnings (E) + Quantitative Description (QD) }+ \\
\text { Predicted Earnings (PE) }\end{array}$ & Cell 1c & Cell 2c \\
Number of participants & 20 & 18 \\
\hline
\end{tabular}




\section{Experiment Participants}

This research uses an $2 \times 3$ mixed experimental design with 38 investors consisting of 15 males and 23 females as the experiment's participants. On average, the subjects are 27 years old. Out of the original 55 subjects, 6 of them could not be analyzed because of incomplete data and 11 people were declared to have failed the manipulation check. Of the 38 subjects, 20 subjects were assigned randomly to the positive earnings group and the other 18 to the negative earnings group.

This experiment was conducted using a personnel based approach, on a voluntary basis and dependent on the willingness of the subjects. Experiments using this approach are conducted on a one-by-one basis for each subject, in contrast to a laboratory experiment which is conducted in a specific room with all the subjects at once. The personnel based approach makes it easy for each subject to determine the time and location, according to his/her availability, for the execution of the experiment.

Recruitment was done through cooperation with the stock exchanges, educational institutions, and various already established relationships in Yogyakarta. ${ }^{3}$ The criteria for the participants in this study are they should be investors who have undertaken some investment activities and have knowledge of, and at least five years experience in, the fields of investment, the capital markets and the analysis of financial statements. The experiment was done by a paper and pencil test.

\section{Research Variables and Their Measurements}

In this experiment, the dependent variable is the investors' evaluations of the company's performance, measured by the investors' earnings forecasts. The investors are asked to interpret an earnings' announcement, and then make an earning's forecast for the next year. This study uses earnings forecasts as a measure of the investors'evaluations of performance, because they are important components for value determinations (Ohlson 1995; Lee 1999).

The independent variables in this study are the factors of the treatment of the $2 \times 3$ mixed design, which are between-subjects for earnings information disclosure (two levels: Positive earnings and negative earnings) and within-subjects for any additional pieces of information when evaluating the company's performance (three levels: Earnings, earnings plus quantitative description, and earnings plus quantitative description plus predicted earnings). First, investors receive a description of the company's business, manipulated for the between-subjects to be either positive or negative information. Investors were also asked to identify the amount of historical earnings, including nonrecurring events (prior-period gain/loss from the sale of fixed assets). This allows the researcher to verify that the investors had previously identified the information needed to adjust for that event when asked later to forecast the earnings.

\footnotetext{
${ }^{3}$ Time for the data's collection for a personnel based approach experiment is longer than for a laboratory experiment. The data collection for this experiment took \pm 6 months (March - August 2015). From 55 subjects, 6 of them could not be analyzed because of incomplete data and 11 people were declared as failing the manipulation check $(22,5 \%) ; 38$ subject $(77,5 \%)$ were declared as being qualified.
} 
This study further manipulated for the within-subjects, whether the investors used the characteristics of the information as a basis for evaluating the company's performance (three types of cases) and determining the amount of the earnings' estimation for the coming year. Then the subjects were given information of an increase or a decrease in the estimated earnings compared with the amount of the current earnings. The subjects also answered questions about the manipulation check.

In this study, quantitative description information is the management's explanation regarding the increase or decrease in sales stated in the earnings' announcement, which occurred during one accounting period. Predicted earnings are defined as the earnings forecast by the company's management, which is expressed as a percentage of the earnings, accompanied by a qualitative explanation of the concrete steps taken by the management to achieve the predicted earnings.

\section{Experiment Material}

The experiment's material uses material taken from Krische's study (2005), with some adjustments to the story's context in order to make it realistic for the Indonesin setting. The case setting is a manufacturing company producing snacks. In this case, an earnings' announcement, either positive or negative, is presented to each group. The positive earnings group was provided with case materials with the initial earnings' value set at Rp530,000.00, and the negative group was provided with case materials with an initial earnings' value of Rp525,000.00.

\section{Experiment Task and Procedure}

The subjects in this study were randomly assigned to two groups, one of which received positive earnings information and the other received negative earnings information. Each participant was given written instructions and case material developed from the study by Krische (2005). All the participants had access to their own calculator.

There were four steps in this experiment. First, the participants were given a description of the company's business. In this step, they were also provided with initial earnings values of $\operatorname{Rp} 530,000.00$ and Rp525,000.00 for the positive and negative earnings announcements, respectively.

Second, the participants were given one of three treatments. These were earnings (E); earnings $(\mathrm{E})+$ quantitative description (QD); and earnings $(\mathrm{E})+$ quantitative description (QD) + predicted parnings (PE) pieces of information. Earnings information (E) contains information about the current and previous years' earnings balances, and their earnings' components. Quantitative description (QD) information is the management's explanation regarding the increase or decrease in sales stated in their earnings announcement, which occurred during one accounting period. Predicted earnings (PE) is the earnings' forecast by the company's management, expressed as a percentage of the earnings accompanied by a qualitative explanation of the concrete steps taken by the management to achieve the predicted earnings. Step three was the demographic data's collection, and the last step was a debriefing for the subjects.

\section{Manipulation Check}

A manipulation check was performed to evaluate the subjects'understanding of the experiment's case material. The manipulation check was done after all the treatments were given. The subjects were asked to estimate future earnings and interpret the magnitude 
of the estimation that they made, whether it is higher or lower than the current earnings. The magnitude of the estimation is said to be higher when there is an increase of Rp10,000.00 or its multiples, and it is said to be lower if there is a decrease of Rp10,000.00 or multiples thereof. If a subject did not answer as instructed, then the subject was declared as being unqualified. The estimation magnitude of Rp10,000.00 or its multiples is either a positive or negative change to the earnings' forecast, which were allowed when the subjects evaluated the firm's performance in the experiment.

\section{Hypotheses Testings}

The data's analysis technique used in this experiment is the Analysis of Variance (ANOVA). The reason to use this analysis method is to compare some of the means differences among the subjects' estimations of the earnings.

\section{Research Results}

\section{Hypotheses Testing Results}

Table 3 shows the means of the investors' earnings forecasts for the $2 \times 3$ mixed design. The subjects responded positively from Rp530,000.00 to Rp541,000.00 for positive Earnings (E) information, which increased to Rp 551,000.00 for positive Earnings (E) + Quantitative Description (QD) information, and increased again to Rp564,000.00 for positive Earnings (E) + Quantitatve Description (QD) + Predicted Earnings (PE) pieces of information.

Table 3 also shows the subjects responded negatively to negative information. The subjects had a negative response from Rp525,000.00 to Rp506,111.11 for negative Earnings (E) information, decreasing to Rp496,666.67 for negative Earnings (E) + Quantitatve Description (QD) pieces of in-

Table 2. Hypotheses Testing

\begin{tabular}{|c|c|c|}
\hline No. & Hypotheses & Testing Ways \\
\hline 1 & $\begin{array}{l}\mathrm{H}_{1} \text { : Prospect Effect } \\
\quad \text { for Single } \\
\text { Information }\end{array}$ & $\begin{array}{l}\text { Comparing the adjustment scale for negative earnings with the } \\
\text { adjustment scale for positive earnings: } \\
\text { Abs }\left(\text { Cell } 2 \mathrm{a}-\mathrm{Rp} 525,000.00^{\mathrm{a}}\right)>\left(\text { Cell } 1 \mathrm{a}-\mathrm{Rp} 530,000.00^{\mathrm{b}}\right)\end{array}$ \\
\hline 2 & $\begin{array}{c}\mathrm{H}_{2}: \text { Prospect effect } \\
\text { debiased for } \\
\text { multiple pieces } \\
\text { of information }\end{array}$ & $\begin{array}{l}\text { Comparing the adjustment scale for negative earnings }+ \text { additional } \\
\text { information with the adjustment scale for positive earnings }+ \\
\text { additional pieces of information: } \\
\text { a. Prospect effect debiased of Qualitative Description (QD): } \\
\quad \text { Abs }(\text { Cell } 2 b-\text { Cell } 2 \mathrm{a}) \leq(\text { Cell } 1 \mathrm{~b}-\text { Cell } 1 \mathrm{a}) \text {. } \\
\text { b. Prospect effect debiased of Predicted Earnings (PE): } \\
\text { Abs }(\text { Cell } 2 \mathrm{c}-\text { Cell } 2 \mathrm{~b}) \leq \text { (Cell } 1 \mathrm{c}-\text { Cell } 1 \mathrm{~b}) \text {. }\end{array}$ \\
\hline
\end{tabular}

\footnotetext{
Notes:

${ }^{a}$ Initial value of earnings for negative earnings group.

${ }^{\mathrm{b}}$ Initial value of earnings for positive earnings group.
} 
formation, and decreasing again to Rp492,222.22 for negative Earnings (E) + Quantitatve Description (QD) + Predicted Earnings (PE) pieces of information.
Subjects' estimation means for positive and negative pieces of information can be graphically presented as in Figure 1.

\section{Table 3. The Average of Investor's Evaluation (Standard Deviation)}

\begin{tabular}{lcc}
\hline & \multicolumn{2}{c}{ Earnings Information } \\
\cline { 2 - 3 } Characteristic Disclosure & $\begin{array}{c}\text { Positive Earnings (in Rp) } \\
\text { Initial reference point is } \\
\text { Rp530,000.00 }\end{array}$ & $\begin{array}{c}\text { Negative Earnings (in Rp) } \\
\text { Initial reference point is } \\
\text { Rp525,000.00 }\end{array}$ \\
\hline \multirow{2}{*}{ Earnings (E) } & Cell 1a: & Cell 2a: \\
& $541,000.00$ & $506,111.11$ \\
Earnings (E) +Quantitative & $(3,077.94)$ & $(7,583.95)$ \\
Description (QD) & Cell 1b: & Cell 2b: \\
Earnings (E) + Quantitative & $551,000.00$ & $496,666.67$ \\
Description (QD) +Predicted & $(5,525.06)$ & $(7,859.05)$ \\
Earnings (PE) & Cell 1c: & Cell 2c: \\
Total Means & $564,000.00$ & $492,222.22$ \\
\hline
\end{tabular}

Figure 1. Subjects' Mean Evaluations for Positive and Negative Earnings Pieces of Information

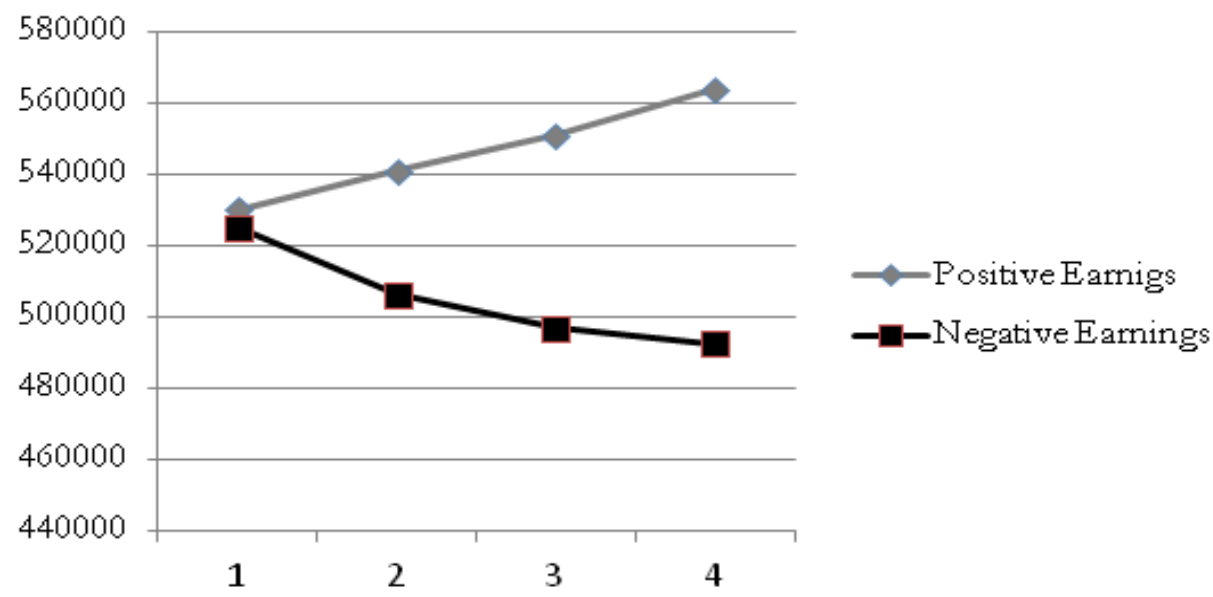




\section{Prospect Effect for Single Earnings Information Hypothesis $\left(\mathrm{H}_{\nu}\right)$}

The first hypothesis $\left(\mathrm{H}_{1}\right)$ tests the prospect effect which is the difference in the subjects' reaction towards positive vs. negative earnings information in a single disclosure. The prospect effect is measured by the absolute difference between the earnings' estimation reaction by the negative earnings group (cell 2a) and the reaction of the positive earnings group (cell 1a). From Table 4, this study shows that the scale average of the subjects' estimation of the earnings for a negative earnings' information disclosure is abs(18,888.89), which is higher than the scale average of the earnings' estimation for a positive information disclosure, which is abs(11,000.00). The result supports $H_{1}$.

\section{Prospect Effect Debiased of Multiple Pieces of Information Hypothesis $\left(\mathrm{H}_{2}\right)$}

The second hypothesis $\left(\mathrm{H}_{2}\right)$ examines the debiasing prospect effect in a situation with multiple pieces of information. It is hypothesized that the additional pieces of information, of a quantitative description and predicted earnings nature, can debias the prospect effect. The research results show the adjustment scale of the subjects' estimation of the earnings for the positive Earnings (E) plus Quantitative Description (QD) information group is $\mathrm{Rp} 10,000.00$ (Rp551,000.00 Rp541,000.00), which is a little higher than that of the subjects' estimations for the negative Earnings (E) plus Quantitative Description (QD) information group which has a mean of Rp-9,444.44 (Rp496,222.22 Rp506,111.11).

Table 4. Prospect Effect Hypothesis Testing for Single Information

\begin{tabular}{|c|c|c|c|c|c|c|}
\hline \multirow{2}{*}{ Comparing Effect } & \multirow{2}{*}{$\begin{array}{l}\text { Adjustment Scale } \\
\text { (in Rp) }\end{array}$} & \multirow{2}{*}{ Difference } & \multicolumn{2}{|c|}{ Levene's Test } & \multicolumn{2}{|c|}{ t-test } \\
\hline & & & & & & \\
\hline $\begin{array}{l}\text { Single Information: } \\
\text { Negative Earnings vs. } \\
\text { Positive Earnings. } \\
\text { Abs(Cell 2a } \\
\text { - Rp525,000.00a }) \text { vs. } \\
(\text { Cell 1a } \\
\text { - Rp530,000.00b) }\end{array}$ & $\begin{array}{l}\operatorname{Abs}(506,111.11-525,000,00)= \\
-18,888.89)>(541,000,00 \\
-530,000.00=11,000.00)\end{array}$ & $7,888.89$ & 12.597 & 0.001 & 18.214 & 0.000 \\
\hline
\end{tabular}

Notes: ${ }^{a}$ Initial value of earnings for negative earnings group; ${ }^{b}$ Initial value of earnings for positive earnings group. 
The hypothesis tested the result by using an independent sample t-test, which showed a t-value of 24.402 and $p=0.000$ (see Table 5). It means that no prospects effect occurred in the future earnings estimation due to the subjects' adjustment scale in the positive earnings group, which is Rp10,000.00 higher than the subject's response in the negative earnings group for a mean of Rp-9,444.44. Thus, additional pieces of information on the characteristics of the earnings' announcement (quantitative description) may reduce the prospect effect when investors are only given information about positive or negative earnings announcements. Therefore, Hypothesis 2 is supported.

Table 5 shows the testing results of the debiasing prospect effect for multiple pieces of information in the positive Earnings (E) plus Quantitative Description (QD) plus Predicted Earnings (PE) information group. The results of the adjustment scale of the subjects' earnings estimations for the positive Earnings (E) plus Quantitative Description (QD) plus Predicted Earnings (PE) information group is Rp13,000.00 ( $\mathrm{Rp564,000.00} \mathrm{-}$ Rp551,000.00), which is higher than the ad- justment scale of the subjects' estimations for the negative Earnings (E) plus Quantitative Description (QD) plus Predicted Earnings (PE) information group which has a mean of minus Rp4,444.45 (Rp492,222.22 - Rp496,222.22). This difference is tested using an independent sample t-test and is statistically significant at 0.001 . The result shows that the disclosure of additional pieces of information of a Quantitative Description (QD) plus Predicted Earnings (PE) nature can further debias the prospect effect. Again, Hypothesis 2 is supported.

\section{Discussions}

How the additional pieces of quantitative description and predicted earnings information can mitigate the prospect effect bias in earnings announcements can be explained in detail by Figure 2 .

The prospect effect occurs when people's response to negative information is greater than their response to positive information. In this study, the prospect effect is found for single earnings information. But, when additional information about the earn-

Table 5. Prospect Effect Debiased Hypotheses Testing for Multiple Pieces of Information

\begin{tabular}{|c|c|c|c|c|c|c|}
\hline \multirow{2}{*}{ Comparing Effect } & \multirow{2}{*}{$\begin{array}{l}\text { Adjustment Scale } \\
\quad \text { (in Rp) }\end{array}$} & \multirow{2}{*}{ Difference } & \multicolumn{2}{|c|}{ Levene's Test } & \multicolumn{2}{|c|}{ t-test } \\
\hline & & & & & & \\
\hline $\begin{array}{l}\text { (Negative E+QD) vs, } \\
\text { (Positive E+QD) } \\
\text { Abs(Cell 2b - Cell 2a) } \\
\text { vs (Cell 1b - Cell 1a) }\end{array}$ & $\begin{array}{l}\operatorname{Abs}(496,222.22-506,111.11= \\
-9,444.44)<(551,000.00 \\
-541,000.00=10,000.00)\end{array}$ & 555.56 & 4.607 & 0.039 & 24.402 & 0.000 \\
\hline $\begin{array}{l}\text { (Negative E+QD+PE) } \\
\text { vs, (Positive E } \\
+ \text { QD +PE) } \\
\text { Abs(Cell 2c - Cell 2b) } \\
\text { vs (cell 1c - Cell 1b) }\end{array}$ & $\begin{array}{l}\operatorname{Abs}(492,222.22-496,222.22= \\
-4,444.45)<564,000.00 \\
-551,000.00=13,000.00)\end{array}$ & $8,555.55$ & 0.918 & 0.344 & 32.603 & 0.001 \\
\hline
\end{tabular}


Figure 2. Debiasing Prospect Effect

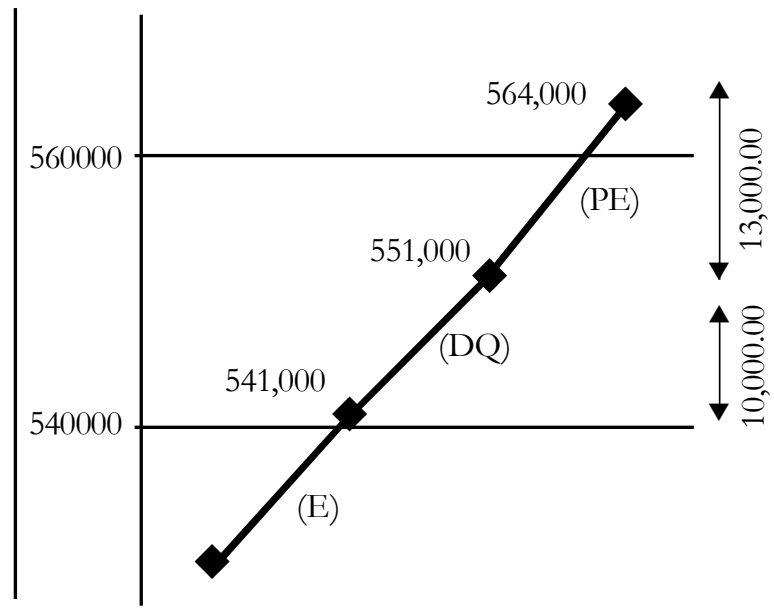

(a) Positive Information

ings' characteristic is added, the prospect effect is mitigated.

Instead of creating a greater response, additional information about the negative Quantitative Description (DE) over earnings information has a lesser response (Rp9,444.45) than additional information about a positive Quantitative Description (DE) has (Rp10,000.00). The magnitude of the debiasing effect is Rp555.55 (Rp10,000.00 - Rp9,444.45) as seen in Figure 2 .

Similarly, additional information about a negative Predicted Earnings (PE) over earnings information and quantitative description has a lesser response $(-\mathrm{Rp} 4,444.45)$ than additional information of a positive Predicted Earnings (PE) has (Rp13,000.00). The magnitude of the debiasing effect is Rp8,555.55 (Rp13,000.00 - Rp4,444.45) as seen in Figure 2. The total debiasing effects is Rp9,111.10 (Rp555.55 + Rp8,555.55).

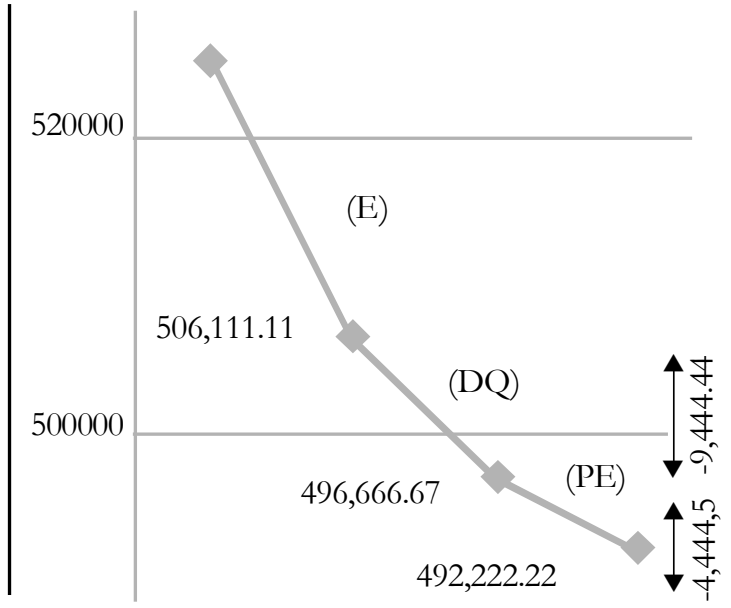

(b) Negative Information

It can be concluded that the additional pieces of information about the Quantitative Description (QD) and Predicted Earnings (PE) both mitigate the prospect effect in earnings announcements with different magnitudes. The debiased effect occurs because additional information that is integrated with the previous information will make the investors' belief stronger, and it will decrease the irrational psychological effect. Clear quantitative description and predicted earnings information, disclosed in the earnings' announcements, would ensure that investors had sufficient information available to them to compute the adjusted earnings, and that is expected to affect the perception of the investors which would then be reflected in their behavior when they make their business decisions.

The debiasing effect of additional information of Quantitative Description (QD) as backward-looking information is smaller than that of additional information of Predictive Earnings (PE) as forward-looking information. 


\section{Conclusion and Implication}

The research results indicate that the prospect effect occurs in the single information and any additional pieces of information in earnings announcements (quantitative description and predicted earnings) can mitigate the prospect effect's bias. Furthermore, the findings indicate that predicted earnings information can mitigate the bias in the prospect effect to a greater degree than quantitative description information can in evaluating a company's future performance. Overall, this study supports Hypotheses $H_{1}$ and $H_{2}$.

The first hypothesis tests whether investors evaluate a company's performance more negatively when they evaluate negative earnings announcements than they do when they evaluate a positive earnings information disclosure. Consistent with $H_{1}$, the scale average of investors' estimations of earnings for negative earnings information disclosure is higher than the scale average of earnings estimations for a positive information disclosure. This result indicates that the prospect effect occurs in the single information disclosure.
The second bypothesis examines the debiasing of the prospect effect by additional multiple pieces of information. Consistent with $H_{2}$, the adjustment scale of investors' evaluations for the positive information group (earnings plus quantitative description) is a little higher than that of investors' evaluations for negative earnings. Further, the testing results of the prospect effect's debiasing for multiple pieces of information show that the adjustment scale of the investors' evaluations for the positive group is higher than the adjustment scale of investors' evaluations for negative earnings. The result shows that the disclosure of additional pieces of information (quantitative description plus predicted earnings) can debias the prospect effect. The findings confirmed the prospect theory (Kahneman and Tversky 1979; Barberis 2013). These results for the debiasing of the prospect effect are expected to trigger fresh research into the behavioral aspects of accounting.

The results suggest that predicted earnings information can mitigate the prospect effect's bias to a greater extent than quantitative description information is able to evalu-

Table 6. Summary of the Results

\begin{tabular}{|c|c|c|}
\hline $\begin{array}{l}\text { Comparing Effect of } \\
\text { Adjustment Scale }\end{array}$ & Mitigated & Explanation \\
\hline $\begin{array}{l}\text { Single Information: } \\
\text { Abs }(-18,888.89)>11,000.00\end{array}$ & - & $\begin{array}{l}\text { - Prospect effect occured, } \\
\text { - ( } \mathrm{H}_{1} \text { supported) }\end{array}$ \\
\hline $\begin{array}{l}\text { Multiple Information of } \\
\text { quantitative description(QD): } \\
\text { Abs(-9,444.44) <10,000.00 }\end{array}$ & $555.55(10,000.00-9,444.45)$ & $\begin{array}{l}\text { - The additional information of } \\
\text { quantitative description can debias } \\
\text { the prospect effect, } \\
\text { - ( } \mathrm{H}_{2} \text { supported) }\end{array}$ \\
\hline $\begin{array}{l}\text { Multiple Information of } \\
\text { quantitative description (QD)+ } \\
\text { predicted earnings (PE): } \\
\text { Abs }(-4,444.45)<13,000.00\end{array}$ & $\begin{array}{l}8,555.55(13,000.00- \\
4,444.45)\end{array}$ & $\begin{array}{l}\text { - The additional information of } \\
\text { quantitative description and predicted } \\
\text { earnings can debias the prospect } \\
\text { effect, } \\
\text { - ( } \mathrm{H}_{2} \text { supported) }\end{array}$ \\
\hline
\end{tabular}


ate a company's future performance. Prior research, such as the study by Baginski et al. (2004) documents that managers often explain their earnings forecasts by linking the forecasted performance to their internal actions and the actions of parties external to the firm. These explanations (or attributions) are potentially important information for investors who engage in strategic analysis of the information in financial statements. Strategic financial analysis involves understanding both a company's internal strategies and competencies, and its external competitive and regulatory environment, to generate profitability forecasts (Palepu et al. 2000). If the attributions are credible, they can enhance the usefulness of the accompanying earnings forecasts by either providing additional information on known links between factors and profitability, or by identifying additional factors to consider in forecasting profits.

This study has important practical implication for firms. Usually, companies are afraid to announce negative information, especially negative earnings information. The reason is because investors will react more irrationally to negative than to positive earn- ings information (the prospect effect's bias). This will disadvantage the companies by decreasing their stock prices. To mitigate this bias, firms can use additional pieces of information. Forward-looking oriented information, such as predictive earnings information, will better mitigate the prospect effect's bias than backward-looking oriented information such as quantitative description infomation.

The limitations of this study are because it used only a small number of participants. This limitation was caused by the difficulty in finding real investors with time to participate in the experiment. The recruitment of the participants was done through cooperation with the stock exchanges, educational institutions, and various relationships.

There are some improvements that can be made by future studies, one being to increase the sample size of the participants. Future research can also use web-based experiments using internet technology. Webbased experimentation can allow for participants from various groups with a wide geographical distribution.

\section{References}

Ajinkya, B., and M. Gift. 1984. Corporate Managers, earnings forecasts and symmetrical adjustment of market expectations. Journal of Accounting Research 22 (2): 425-444.

Baginski, J., M. Hassell, and M. D. Kimbrough. 2004. Why do managers explain their earnings forecasts? Journal of Accounting Research 42 (1 March): 1-29.

Barberis, N. C. 2013. Thirty years of prospect theory in economics: A review and assessment. Journal of Economic Perspectives 27: 173-196.

Bazerman. 1994. Judgment in Managerial Decision Making. Willey \& Sons. Inc.

Bernard, V. L. 1989. Capital markets research in accounting during the 1980's: Critical review. The State of Accounting Research: 72-120. 
Boldt, M. N. 2001. The effects of functional fixation on relative performance evaluations. Academy of Strategic and Organizational Leadership Journal 5 (1): 17-30.

Boles, T. L., and D. M. Messick. 1995. A reverse outcome bias: The influence of multiple reference points on the evaluation of outcomes and decisions. Organizational Behavior and Human Decision Processes 61 (3): $262-275$.

Cooper, D. R., and P. S. Schindler. 2006. Business Research Methods. Singapore, McGraw-Hill/Irwin.

Easton, P., and M. Zmijewski. 1989. Cross-sectional variation in the stock market response to accounting earnings announcements. Journal of Accounting and Economics. 11: 117-141.

Feltham, G. A., and J. A. Ohlson. 1995. Valuation and clean surplus accounting for operating and financial activities. Contemporary Accounting Research 11 (2): 689-731.

Fiegenbaum, A., and H. Thomas. 1988. Attitudes towards risk and the risk-return paradox: Prospect theory explanations. Academy of Management Journal 31: 85-106.

Fiegenbaum, A., and H. Thomas. 1990. Prospect theory and the risk-return association: An empirical examination of 85 industries. Journal of Economic Behavior and Organization 14:187-203.

Foster, G. 1977. Quarterly accounting data: Time-series properties and predictive-ability results. The $A c$ counting Review. 52: 1-21.

Freeka, T. J., and C. F. Lee. 1983. Generalized financial ratio adjustment processes and their implication. Journal of Accounting Research 21: 308-316.

Freeman, R. and S. Tse. 1992. A nonlinear model of security price responses to unexpected earnings. Journal of Accounting Research. 30: 185-209.

Han. J., and J. Wild. 1987. Incremental information in the components of managements' forecasts. Working Paper (March). Michigan State University.

Han. J., and H. Tan. 2007. Investors' Reactions to Management Guidance Forms: The Influence of Multiple Benchmarks. The Accounting Review 82 (2): 521-543.

Harsha, P. D., and M. C. Knapp. 1990. The use of within-and between-subjects experimental designs in behavioral accounting research: A methodological note. Behavioral Research in Accounting 2: 50-62.

Hartono, J. 2004. How, Why and When Investors Revise Their Beliefs to Company Information and Their Implications to Firms Announcement Policy. ANDI Yogyakarta.

Hartono, J., and S. Wahyuni. 2014. Implementation of multiple reference points theory in management guidance information disclosure. Working Paper. Universitas Gadjah Mada.

Hirst, D. E., K. E. Jackson, and L. Koonce. 2003. Improving financial reports by revealing the accuracy of prior estimates. Contemporary Accounting Research 20 (1): 165-193.

Jegers, M. 1991. Prospect theory and the risk-return relation: Some Belgian evidence. Academy of Management Journal 34: 215-225.

Kahneman, D., and A. Tversky. 1979. Prospect theory: An analysis of decision under risk. Econometrica 47 (2 March): 263-291.

King, R., G. Pownall, and G. Waymire. 1990. Expectations adjustments via timely management forecasts: Review, synthesis, and suggestions for future research. Journal of Accounting Literature 9: 113-144.

Klinger, D., and Tsur, I. 2011. Prospect theory and risk-seeking behavior by troubled firms. The Journal of Behavioral Finance, 12: 29-40. 
Kormendi, R. and R. Lipe. 1987. Earnings innovations, earnings persistence, and stock return. Journal of Business. 60: 323-345.

Krische, S. D. 2005. Investors'evaluations of strategic prior-period benchmark disclosure in earnings announcements. The Accounting review 80 (1): 243-268.

Lakonishok, J., and S. Seymour. 1989. Past price changes and current trading volume. Journal of Portfolio Management, 15: 18-24.

Lee, C. M. C. 1999. Accountings-based valuation: Impact on business practices and research. Accounting Horizons 13 (4): 413-425.

Lehner, J. M. 2000. Shifts of reference points for framing of strategic decisions and changing risk-return associations. Management Science 46: 63-76.

Lev, B. 1969. Industry averages as targets for financial ratios. Journal of Accounting Research 7: 290-299.

Libby, R., R. J. Bloomfield, and M. W. Nelson. 2002. Experimental research in financial accounting. Accounting, Organizations and Society 27 (8): 775-810.

Libby, R., H. T. Tan, and J. E. Hunton. 2006. Does the form of managements' earnings guidance affect analysts' earnings forecasts? The Accounting Review 81 (1): 251-270.

Maines, L. A., and L. S. McDaniel. 2000. Effect of comprehensive-income characteristics on nonprofessional investors'judgments: The role of financial-statement presentation format. The Accounting Review 75 (2): 179-207.

Odean, T. 1998. Are investors reluctant to realize their loss? Journal of Finance 53: 1775-1798.

Ohlson, J. A. 1995. Earnings, book values, and dividends in security valuation. Contemporary Accounting Research 11 (2): 661-687.

Palepu, K., P. Healy, and V. Bernard. 2000. Business Analysis and Valuation. Secon Edition, Mason, OH: South-Western College Publishing.

Pattel, J. 1976. Corporate forecasts of earnings per share and stock price behavior: Empirical tests. Journal of Accounting Research (Autumn): 246-276.

Penman, S. 1980. An empirical investigation of the voluntary disclosure of corporate earnings forecasts. Journal of Accounting Research (Spring): 132-160.

Pownall, G., and G. Waymire. 1989. Voluntary Disclosure Credibility and Securities Prices: Evidence from management earnings forecasts, 1969-73. Journal of Accounting Research 27 (2 Autumn): 227-245.

Pownall, G., C. Wasley, and G. Waymire. 1993. The stock price effects of alternative types of management earnings forecasts. The Accounting Review 68 (October): 896-912.

Schrand, C. M., and B. R. Walther. 2000. Strategic Benchmarks in Earnings Announcements: The Selective Disclosure of Prior-Period Earnings Components.The Accounting Review 75 (2): 151-177.

Sinha, T. 1994. Prospect theory and risk return association: Another look. Journal of Economic Behavior and Organization 24: 225-231.

Stracca, L. 2002. Behavioral finance and aggregate market behavior: Where do we stand? Working Paper. European Central Bank.

Trueman, B. 1986. Why do managers voluntarily release earnings forecast? Journal of Accounting and Economics (January): 53-72. 
Wahyuni, S., and J. Hartono. 2010. Strategic disclosure of multiple benchmarks in earnings announcements: An examination of investor behavior based on internal and external factors in the performance evaluation. The Indonesian Journal of Accounting Research 13(Mei): 149-166.

Wahyuni, S., and J. Hartono. 2012. Reminder effect and anchoring-adjustment in earnings announcement. Implementation of prior-period benchmark disclosure strategy. Journal of Indonesian Economy and Business 27 (September): 390-405.

Waymire, G. 1984. Additional evidence on the information content of management earnings forecast. Journal of Accounting Research (Autumn): 703-718. 
